\title{
Fire propagation over combustible exterior facades exposed to intensified flame in Japan
}

\author{
Yuhei Nishio $^{1}$, Hideki Yoshioka ${ }^{2, a}$ Takafumi Noguchi $^{1}$, Manabu Kanematsu ${ }^{3}$, Tatsuo Ando ${ }^{1}$, \\ Masamichi Tamura ${ }^{1}$ and Yoshihiro Hase ${ }^{4}$ \\ ${ }^{1}$ The University of Tokyo, Japan \\ ${ }^{2}$ National Institute for Land and Infrastructure Management (NILIM), Japan \\ ${ }^{3}$ Tokyo University of Science, Japan \\ ${ }^{4}$ Mitsubishi Plastics, Inc., Japan
}

\begin{abstract}
With regard to fire safety for exterior walls of a building, fire-resistance performance is considered, according to the current Building Standard Law of Japan. And it was revealed that the fire safety is not specifically regulated from the viewpoint of reactionto-fire performance, such as fire propagation caused by combustible materials or products installed on the exterior side of fire-resistant load-bearing walls. Actual fire incidents in the world have shown that massive façade fire could occur at the exterior side of building wall even when the wall itself is fire resistant. In previous studies of the authors, a test method of façade fire was proposed for evaluating the vertical fire propagation over an external wall within the same building [1, 2]. Based on these studies, new domestic standard test method was established in Japan as JIS A 1310: 2015, "Test method for fire propagation over building façades" at the end of January 2015 [3]. But there was the argument that heat output of burner inside the combustion chamber was not sufficiently high in the previous study. In this paper, results of fire tests on combustible façades are discussed from the viewpoints of different strength of flame exposing facade. In this research, it was clearly found that JIS A 1310 with heat output of $900 \mathrm{~kW}$ could be applicable for evaluating fire propagation behaviour over various types of combustible exterior façades.
\end{abstract}

\section{INTRODUCTION}

According to the current Building Standard Law of Japan, it is not restricted to install combustible materials over their exterior walls as long as fireproof buildings retain their required fire resistance performances. However, installation of combustible material over the exterior wall could cause largescale fire propagation. In previous studies of authors, façade test method for evaluation of fire propagation over combustible cladding was proposed, using various types of combustible façade specimens [1, 2]. Heat output of gas burner in a combustion chamber was set $600 \mathrm{~kW}$, because temperature in the chamber was about $1000^{\circ} \mathrm{C}$ and temperature at lintel was about $900{ }^{\circ} \mathrm{C}$, which are near at real fire condition.

\footnotetext{
a e-mail: yoshioka-h92te@nilim.go.jp
}

This is an Open Access article distributed under the terms of the Creative Commons Attribution License 2.0, which permits unrestricted use, distribution, and reproduction in any medium, provided the original work is properly cited. 


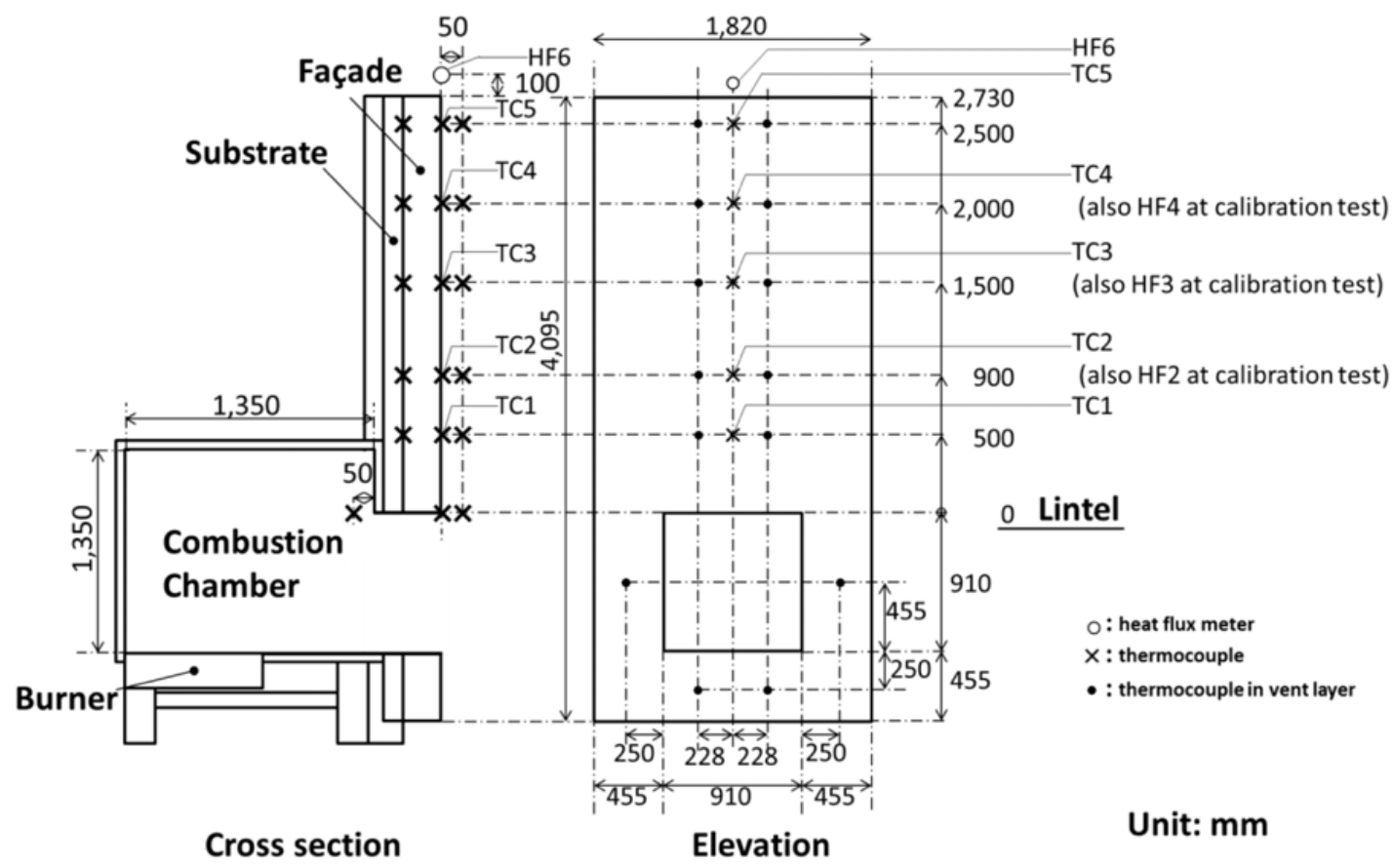

Figure 1. Cross section and elevation of test facility of JIS A 1310 including positons of thermocouples and heat flux meters.

However, some severe fire incidents occurred at high rise building covered with aluminium composite panel in Korea and Dubai, and a fire propagation also occurred at a building coated with resin paint in Japan even thought it was a small fire in scale. Compared with these combustible façade fires in actual cases, flame propagation at fire test with some combustible façade in previous study were smaller. It was considered that heat output in the previous study could not verify fire propagation over combustible façade properly.

The purpose of this paper is to investigate properties of fire propagation over various types of combustible façade specimens which could be applied in actual buildings with higher heat output from combustion chamber, compared with the previous study and to verify the proper heat intensity on JIS A 1310 as the test method for evaluating properties of fire propagation over combustible exterior façades as the result of the investigation.

\section{TEST METHOD}

Tests were performed according to JIS A 1310, which is vertical and façade-shaped simulating ejected flame from opening after flash over. Test facility of JIS A 1310 is shown in Fig. 1. As for test procedures, a propane burner is ignited when the test is initiated, and continues to supply a certain amount of propane gas constantly for 20 minutes by using a flow meter. For setting flow rate of propane gas, the heat output of propane burner was controlled by the oxygen consumption method in advance. A video camera was located diagonally opposite to the specimen's surface to visually observe fire propagation behaviour over combustible façade surface.

Unlike ISO 13785-2[4], specimen's size is smaller (from lintel to specimen's top is about $2.7 \mathrm{~m}$ ) and opening size is not rectangular but square (about $0.9 \mathrm{~m}$ square). And specimen's shape is flat surface without wing-wall unlike ISO 13785-2. 


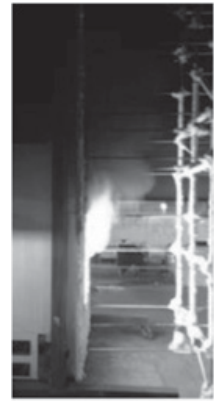

Side view

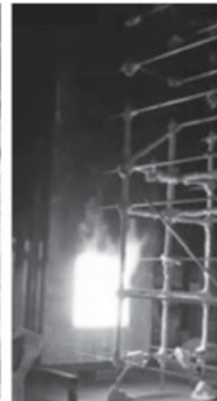

Front view Heat output of $600 \mathrm{~kW}$

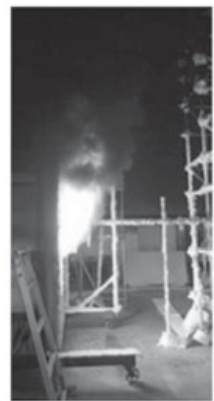

Side view

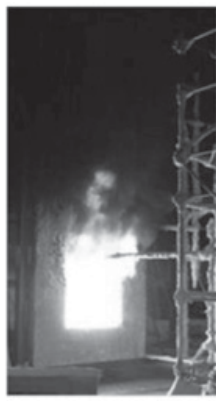

Front view Heat output of $900 \mathrm{~kW}$

Figure 2. Photograph of flame venting through the opening at a calibration test.

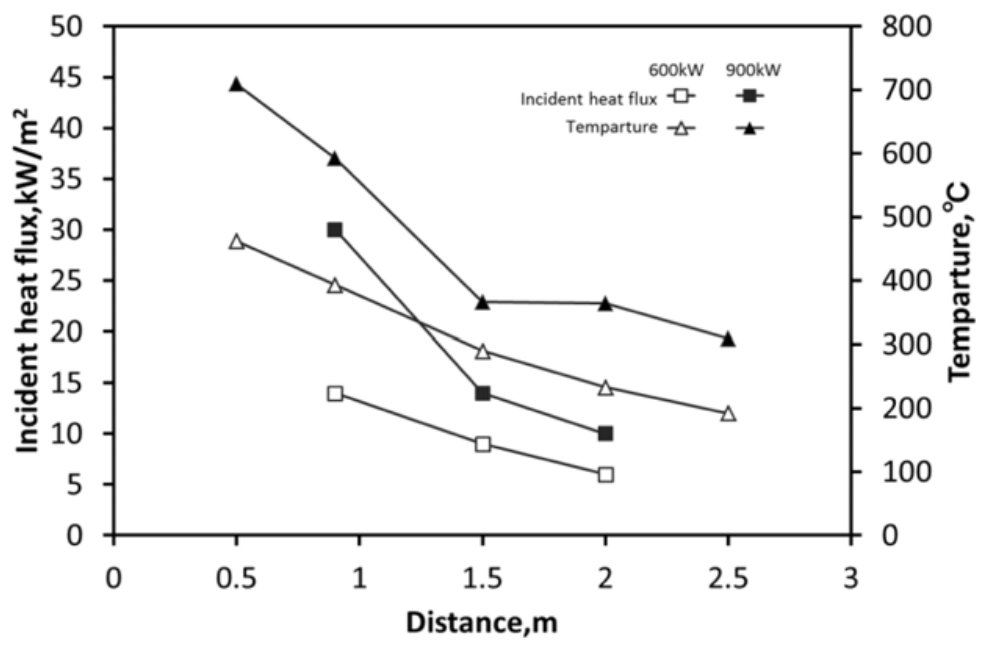

Figure 3. Calibration test result about relationship between distance above the opening and façade surface temperatures and façade surface incident heat fluxes.

\section{FLAME PROPERTIES WITH NONCOMBUSTIBLE FACADE}

As a calibration test, a fire test was performed with a non-combustible façade which surface was covered with $25 \mathrm{~mm}$ thick ceramic fibre blanket. Heat flux meters were installed at HF2, HF3 and HF4, and thermocouples were installed at the position indicated in Fig. 1 (TC1 to TC5).

The author conducted experiments according to JIS A 1310 with a heat output of $600 \mathrm{~kW}$ in the previous study. In this research, fire tests were conducted with a higher heat output than the previous study (about $900 \mathrm{~kW}$ ).

Figure 2 shows appearance of venting flame in stable condition at a calibration test. It seems that flame in the case of $900 \mathrm{~kW}$ was higher, thicker and along the façade surface longer than flame in the case of $600 \mathrm{~kW}$. Figure 3 shows comparison between heat output of $600 \mathrm{~kW}$ and $900 \mathrm{~kW}$ about average façade surface temperatures and façade surface incident heat fluxes in stable condition. At $0.5 \mathrm{~m}$ and $0.9 \mathrm{~m}$ upward from the lintel, temperature and incident heat flux on façade surface with $900 \mathrm{~kW}$ are much higher than that of $600 \mathrm{~kW}$, especially at $0.9 \mathrm{~m}$ upward from the lintel, incident heat flux on façade surface was about twice as much of $600 \mathrm{~kW}$. The difference between temperatures and incident 
Table 1. Details of façade specimens.

\begin{tabular}{|c|c|c|c|c|}
\hline No. & $\begin{array}{l}\text { Heat release } \\
\text { Rate (HRR) }\end{array}$ & Details & Specimen & Category \\
\hline $1-\mathrm{a}$ & $600 \mathrm{~kW}$ & EPS(100 mm); Acrylic resin mortar ( $2 \mathrm{~mm}$ thick); & ETICS & Exterior \\
\hline $1-b$ & $900 \mathrm{~kW}$ & $\begin{array}{l}\text { Reinforcing net(single layer); Edge: back-wrapping; } \\
\text { Finishing material: combustible }\end{array}$ & $100 \mathrm{~mm}$ & $\begin{array}{l}\text { thermal } \\
\text { insulation }\end{array}$ \\
\hline $2-\mathrm{a}$ & $600 \mathrm{~kW}$ & Same as No.1 except thickness of EPS $(200 \mathrm{~mm})$ & ETICS & \\
\hline $2-b$ & $900 \mathrm{~kW}$ & & $200 \mathrm{~mm}$ & \\
\hline $3-\mathrm{a}$ & $600 \mathrm{~kW}$ & Horizontal planks of Japanese cedar on furring & W & \\
\hline $3-b$ & $900 \mathrm{~kW}$ & & & Wooden \\
\hline $\begin{array}{l}4-\mathrm{a} \\
4-\mathrm{b}\end{array}$ & $\begin{array}{l}600 \mathrm{~kW} \\
900 \mathrm{~kW}\end{array}$ & $\begin{array}{l}\text { Horizontal planks of Japanese cedar with chemical } \\
\text { treatment on furring }\end{array}$ & W-FR & façade \\
\hline $\begin{array}{l}5-\mathrm{a} \\
5-\mathrm{b}\end{array}$ & $600 \mathrm{~kW}$ & Core: polyethylene $(3 \mathrm{~mm}$ thick); Surface: aluminium & $\mathrm{ACP}$ & Aluminium \\
\hline $\begin{array}{l}6-\mathrm{c} \\
6-\mathrm{a} \\
6-\mathrm{b}\end{array}$ & $\begin{array}{l}600 \mathrm{~kW} \\
900 \mathrm{~kW}\end{array}$ & $\begin{array}{l}\text { Core: } \mathrm{Al}(\mathrm{OH})_{3}+\text { polyethylene }(3 \mathrm{~mm} \text { thick }) \text {; Surface: } \\
\text { aluminium facing }(0.5 \mathrm{~mm} \text { thick }) \text { on both sides }\end{array}$ & ACP-FR & composite panel \\
\hline $\begin{array}{l}7-\mathrm{a} \\
7-\mathrm{b}\end{array}$ & $\begin{array}{l}600 \mathrm{~kW} \\
900 \mathrm{~kW}\end{array}$ & $\begin{array}{l}\text { Water resistant exterior finish paint, } \\
\text { (Dry film thickness: } 2 \text { to } 3 \mathrm{~mm} \text { ) }\end{array}$ & $\mathrm{RP}$ & Resinous paint \\
\hline
\end{tabular}

heat fluxes on façade surface of $600 \mathrm{~kW}$ and $900 \mathrm{~kW}$ is relatively smaller at $1.5 \mathrm{~m}$ or higher distance from the lintel.

\section{SPECIMENS}

Table 1 summarizes overall information on façade specimens. All the specimens are installed upon substrate, calcium silicate boards. Attached "-a" at end of specimen's number were conducted experiments at heat output of $600 \mathrm{~kW}$, while attached "-b" at end of specimen's number were at $900 \mathrm{~kW}$. As for an exterior thermal insulation system, which is composed of EPS boards, glass fibre mesh, adhesive (mortar based) and finish coat (cement-based), the authors conducted fire tests for two different thicknesses of EPS $(100 \mathrm{~mm}$ and $200 \mathrm{~mm})$. As for wooden façade, which have recently been used for decorative purposes at exterior façade, two types of specimens were used. The difference is mainly whether applied chemical treatment to enhance fire-retardant performance or not. Specimens Nos. 5 and 6 are thin aluminium composite panels. Both surfaces are covered by aluminium facings. The core material of No. 5 is polyethylene, while that of No. 6 is composed of $30 \%$ weight polyethylene and $70 \%$ weight aluminium hydroxide $\left(\mathrm{Al}(\mathrm{OH})_{3}\right)$ for fire-retardant purpose. The composite panel of No. 6 holds various fire-safety certifications around the world. No. 7 is coated with water-resistant exterior finish paint, coated over the substrate. Only specimen Nos. 5 and 6 have a vertical joint at the center line of the façade, in order to make a weak point which is possible even in an actual building.

\section{FIRE PROPAGATION BEHAVIOUR IN COMBUSTIBLE FAÇADE}

Observation of fire propagation behaviour is an essential element to understand fire performance of combustible façade. As follows, we show fire propagation behaviours in each specimen.

Figure 4 shows fire propagation behaviours in specimens of exterior thermal insulation system with $100 \mathrm{~mm}$ thickness of EPS. Although fire propagation at No. 1-a was slightly visible from 4 to 5 min after the start of the test, fire propagation at No. 1-b was easily visible from 1 to $5 \mathrm{~min}$.

Figure 5 shows fire propagation behaviours in specimens with exterior thermal insulation system with $200 \mathrm{~mm}$ thickness of EPS. Different from the case of $100 \mathrm{~mm}$ thick EPS, fire propagations were observed at both specimens (No. 2-a and No. 2-b). Although fire propagation at No. 2-b was observed from $1.5 \mathrm{~min}$ after the start of the test, fire propagation at No. 2-a was not visible until 5 min. 
$2^{\text {nd }}$ International Seminar for Fire Safety of Facades, Lund (Sweden), 2016

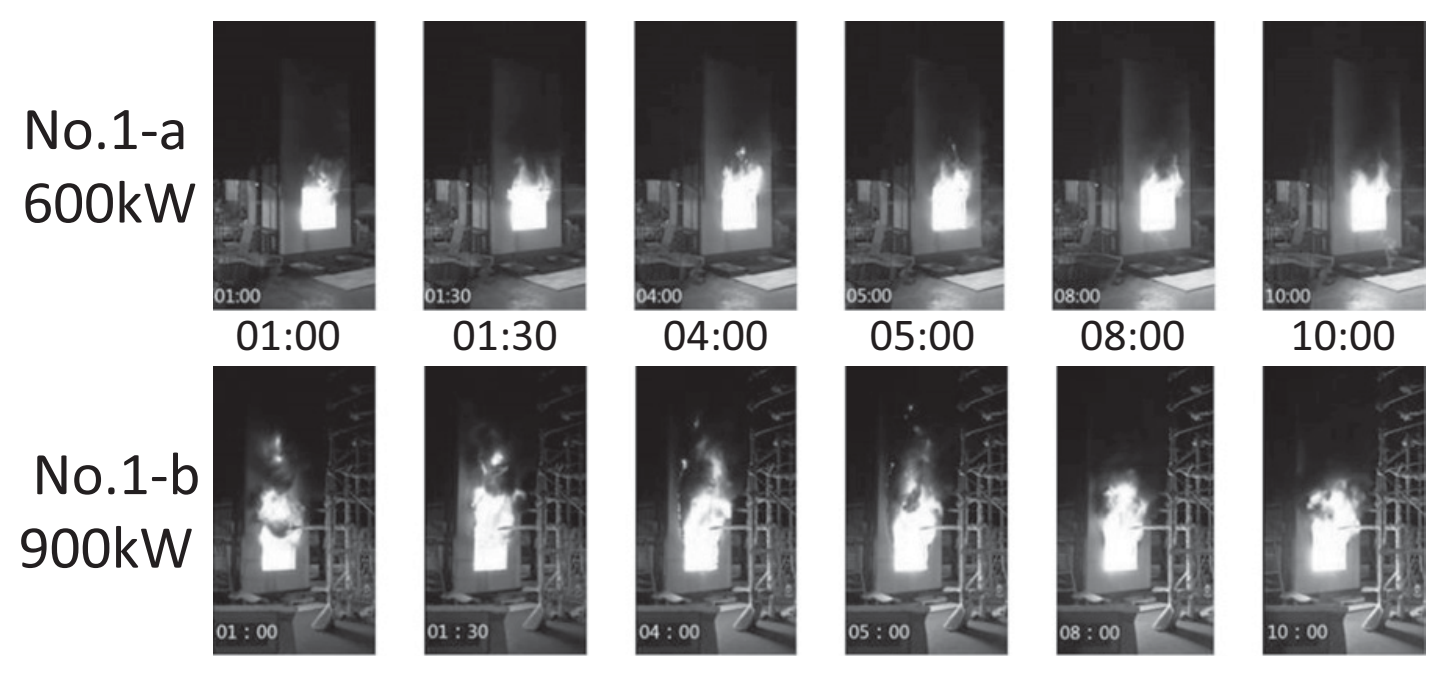

Figure 4. Specimens of exterior thermal insulation system with 100mm thick EPS (No. 1-a and 1-b) 1, 1.5, 4, 5, 8 and $10 \mathrm{~min}$ after the start of the test.

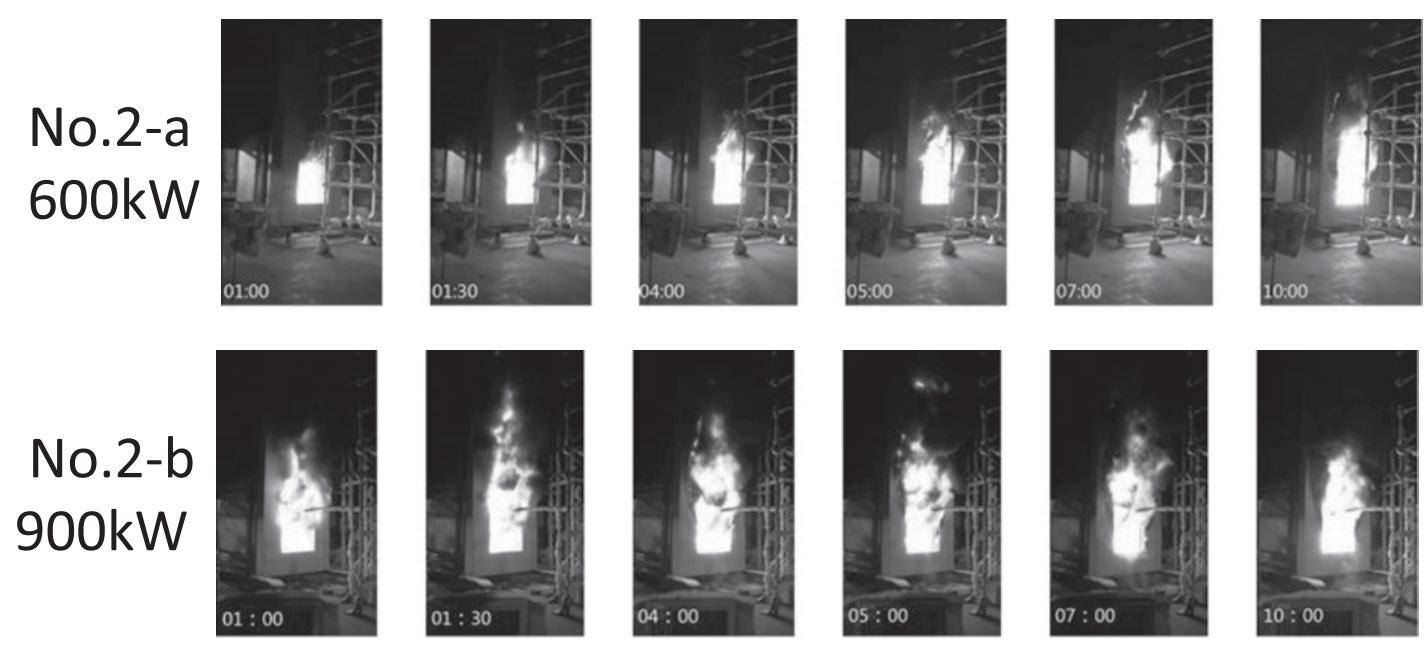

Figure 5. Specimens of exterior thermal insulation system with $200 \mathrm{~mm}$ thick EPS (No. 2-a and 2-b) 1, 1.5, 4, 5, 7 and $10 \mathrm{~min}$ after the start of the test.

Figure 6 shows fire propagation behaviours in specimens of wooden façade with no fire-retardant treatment. Although fire propagation at No. 3-a was occurred from $13.5 \mathrm{~min}$ after the start of the test, fire propagation at No. 3-b easily occurred from $1 \mathrm{~min}$ and continued until the end of the experiment.

Figure 7 shows fire propagation behaviours in specimens of wooden façade with chemical fireretardant treatment. In spite of different flaming properties, remarkable fire propagations were not observed at both specimens (No. 4-a and No. 4-b).

Figure 8 shows fire propagation behaviours in specimens of aluminium composite panel with polyethylene core. At No. 5-a, fire propagation occurred 10 min after the start of the test and only the vertical joint of panels located on the centre line of the specimen were seriously damaged. On the other hand, at No. 5-b, fire propagation occurred 3 min after the start of the test and many parts of the specimen were burned out $8 \mathrm{~min}$ after the start of the test. 

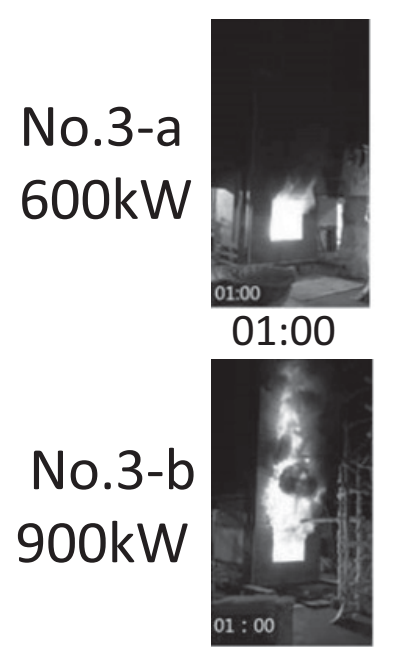
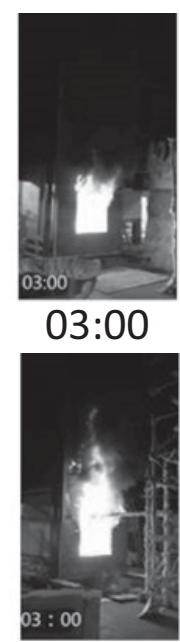
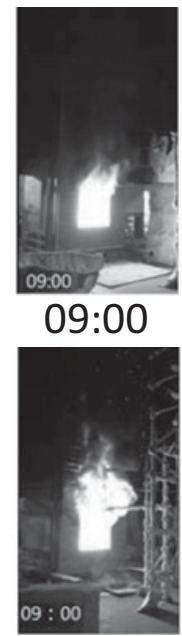
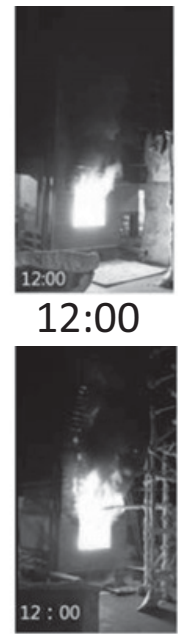
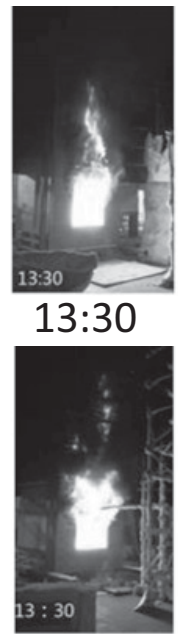
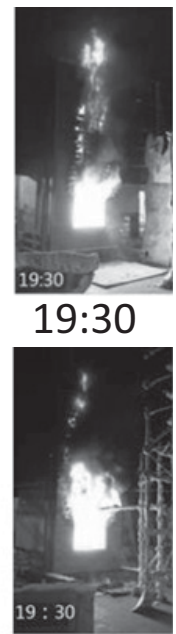

Figure 6. Specimens of wooden façade with no fire-retardant treatment (No. 3-a and 3-b) 1, 2, 9, $12,13.5$ and $19.5 \mathrm{~min}$ after the start of the test.

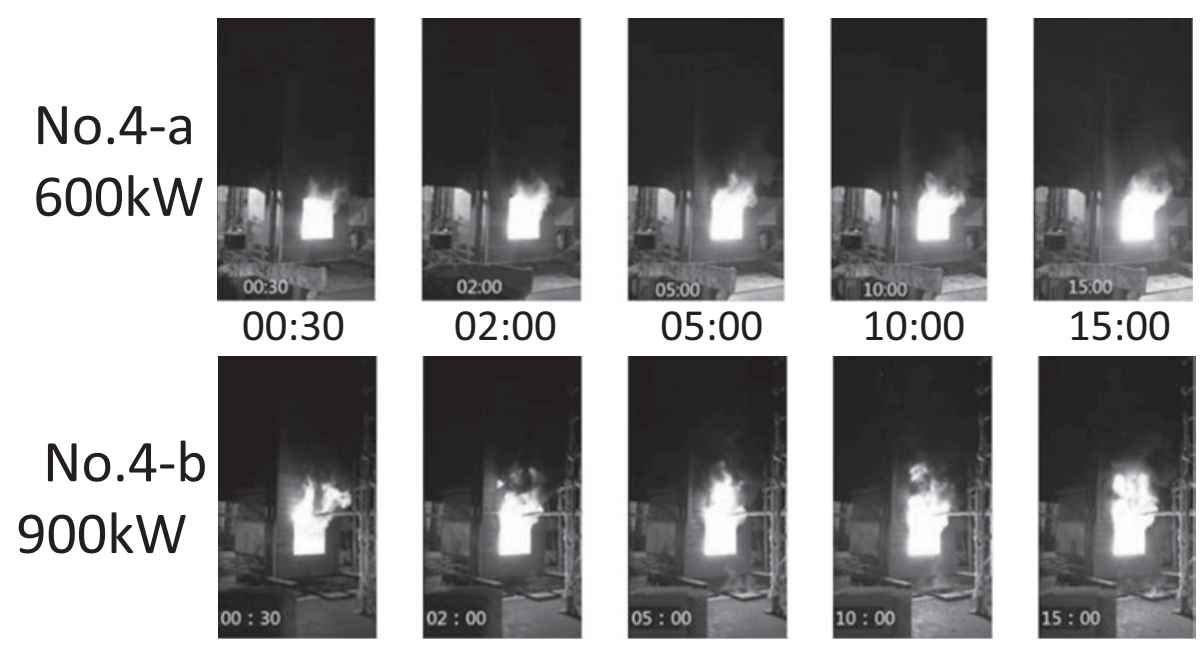

Figure 7. Specimens of wooden façade with chemical fire-retardant treatment (No. 4-a and 4-b) 0.5, 2, 5, 10 and 15 min after the start of the test.

Figure 9 shows fire propagation behaviours in specimens of aluminium composite panel with fireretardant polyethylene core. Severe fire propagation did not occur with No. 6-a. On the other hand, with No. 6-b, although fire propagation occurred to some extent at $5 \mathrm{~min}$ after the start of the test, severe fire propagation, such as observed at No. 5-b, did not occur.

Figure 10 shows fire propagation behaviours of specimens coated with resinous paint. At No. 7-a, slight fire propagation occurred $3.5 \mathrm{~min}$ after the start of the test. On the other hand, at No. 7-b, fire propagated to the top of the specimens immediately and larger fire propagation occurred, but flames mostly disappeared just 5 min after the start of the test.

Compared with the experiments conducted by heat output of $600 \mathrm{~kW}$, clearly different and more severe fire propagation behaviours were observed in some specimens, such as wooden façade without 
$2^{\text {nd }}$ International Seminar for Fire Safety of Facades, Lund (Sweden), 2016
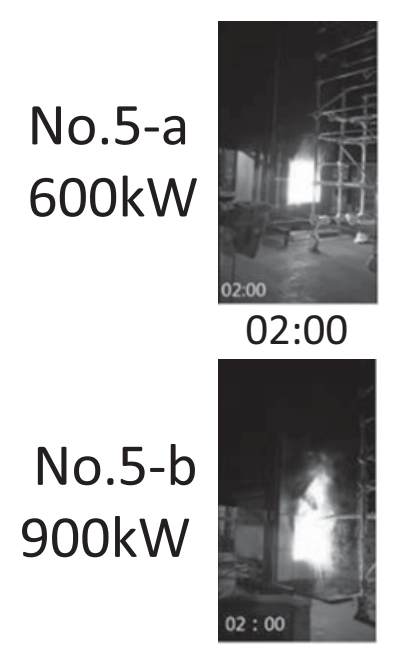
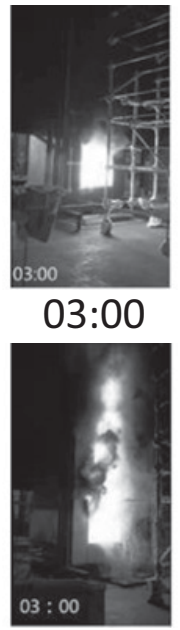
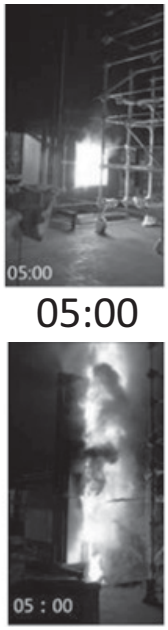
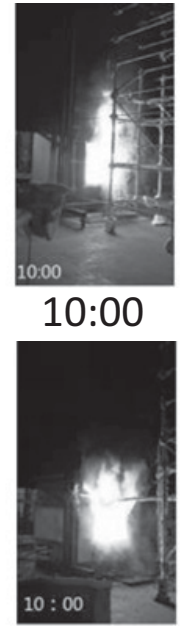
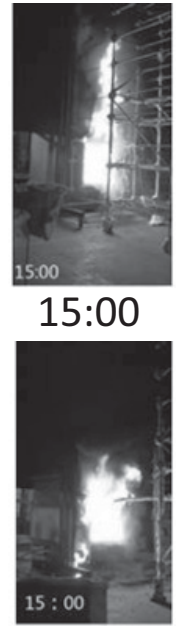
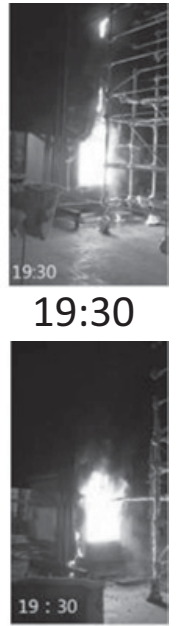

Figure 8. Specimens of aluminium composite panel with polyethylene core (No. 5-a and 5-b) 2, 3, 5, 10, 15 and $19.5 \mathrm{~min}$ after the start of the test.

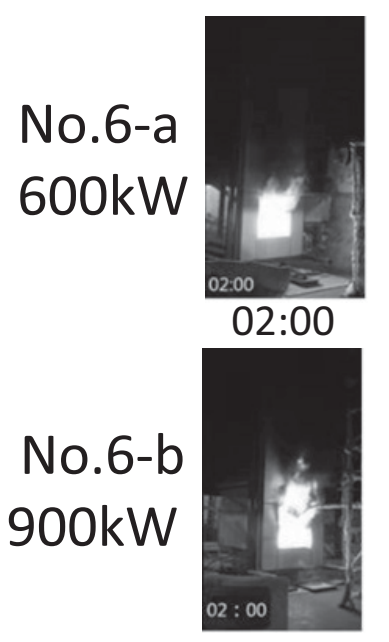

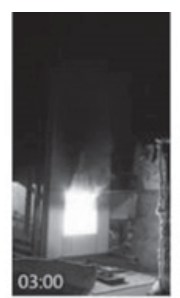
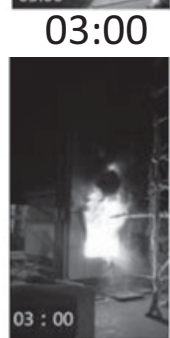
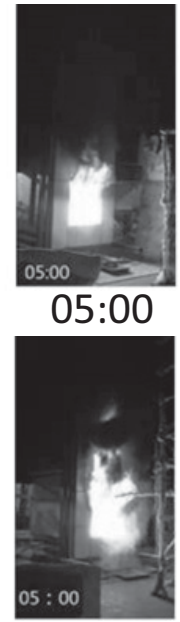
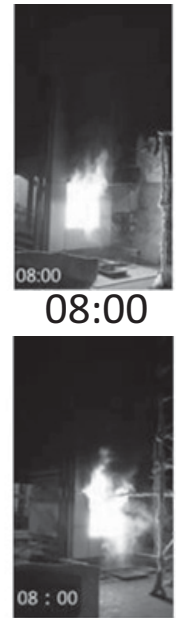
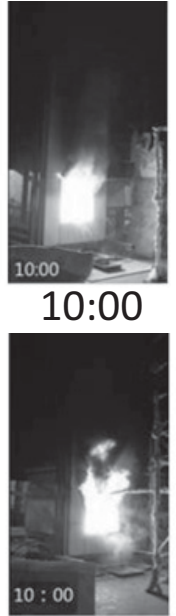
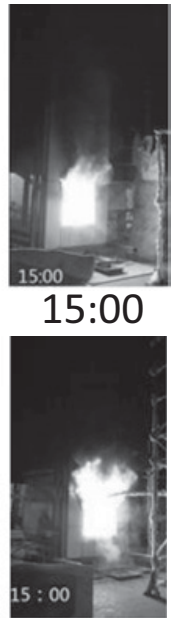

Figure 9. Specimens of aluminium composite panel with fire-retardant polyethylene core (No. 6-a and 6-b) 2, 3, 5, 8,10 and $15 \mathrm{~min}$ after the start of the test.

fire-retardant treatment, aluminium composite panel with polyethylene core and rein paint. On the other hand, no severe fire propagation occurred even though intensified flame in specimens with fire-retardant treatment such as No. 4 and No. 6. It is concluded that fire propagation could occur in the fire test at heat output of $900 \mathrm{~kW}$, while no severe flame propagation observed at the fire test with heat output of $600 \mathrm{~kW}$.

\section{COMOPARISION OF $600 \mathrm{KW}$ AND $900 \mathrm{KW}$}

Figures 11 and 12 show correlation of respectively, peak flame height and peak incident heat flux on the specimen's top (HF6 in Fig. 1) between test results with heat output of $600 \mathrm{~kW}$ and $900 \mathrm{~kW}$. Flame height means the height from the lintel to the point which measured over $500{ }^{\circ} \mathrm{C}$ and was most distant 

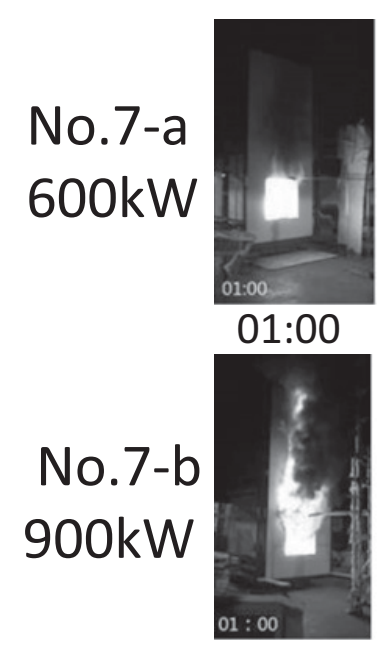
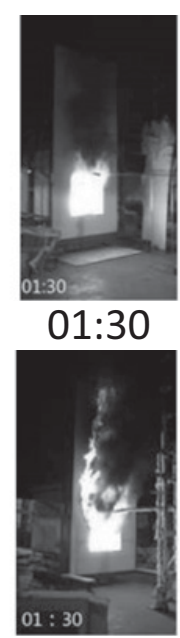
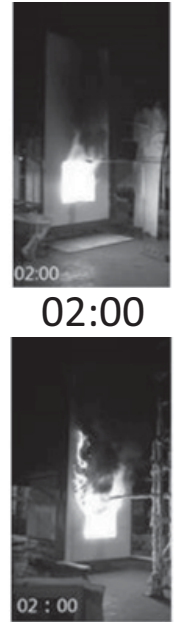
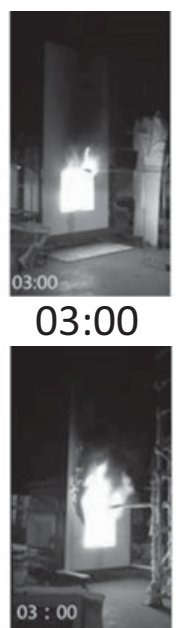
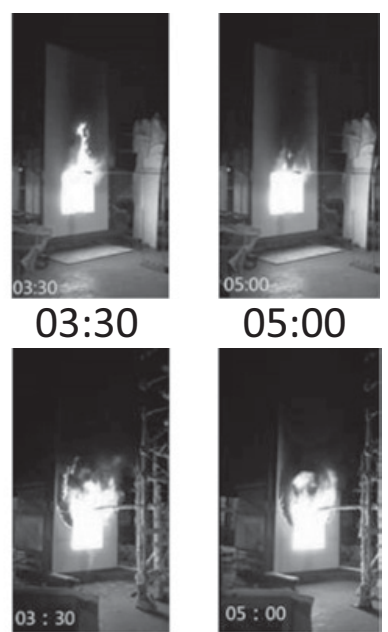

Figure 10. Specimens with resin paint (No. 7-a and 7-b) 1, 1.5, 2, 3, 3.5 and 5 min after the start of the test.

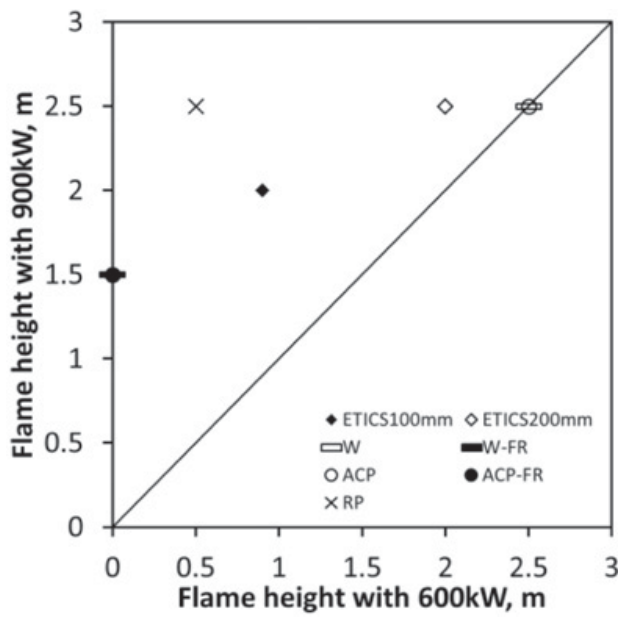

Figure 11. Peak flame height.

from the lintel (chosen among TC1 to TC5). Flame height was $0 \mathrm{~m}$ if the peak temperature at TC1 didn't exceed $500^{\circ} \mathrm{C}$.

With respect to flame height, flame heights with $900 \mathrm{~kW}$ were obviously higher because original flame height with no combustible façade was higher. For the distance from the lintel to specimen's top was about $2.7 \mathrm{~m}$, maximum flame height were $2.5 \mathrm{~m}$ even though flame was likely to spread over the specimen's top, especially in the case of $900 \mathrm{~kW}$. Difference between $600 \mathrm{~kW}$ and $900 \mathrm{~kW}$ about flame height was greater at specimens with resin paint.

With respect to heat flux at specimen's top (HF6), most of the specimens with heat output of $600 \mathrm{~kW}$ had about $10 \mathrm{~kW} / \mathrm{m}^{2}$ expect for aluminium composite panel with polyethylene core and wooden façade with no fire-retardant treatment. On the other hand, specimens with heat output of $900 \mathrm{~kW}$ had different values at HF6 in each specimen. Especially, at specimens of aluminium composite panel and resin paint, at which larger fire propagation were observed, relatively high heat fluxes were measured. Heat fluxes at specimen's top with heat output of $900 \mathrm{~kW}$ showed clear difference from specimens exposed of $600 \mathrm{~kW}$. 


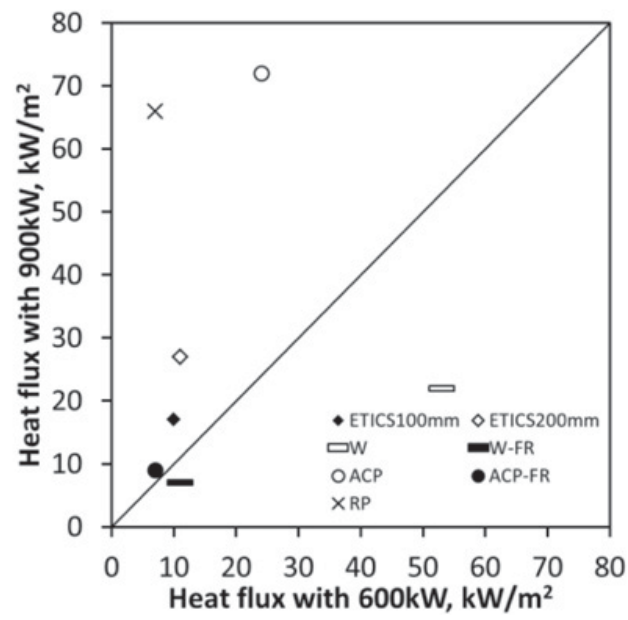

Figure 12. Peak incident heat flux on HF6.

\section{CONCLUSION}

As a result of conducting JIS A 1310 test with intensified flame, it becomes clearer to distinguish between combustible exterior façades with higher performance and those which propagates fire easily compared with the previous study.

Indeed JIS A 1310 with heat output of $600 \mathrm{~kW}$ could classify combustible exterior façades in which severe fire propagation occurred (specimens such as aluminium composite panel with polyethylene core, resin paint and wood with no treatment for fire retardancy) and those in which severe fire propagation didn't occur though ignition and combustion occurred by flame from the opening (specimens such as aluminium composite panel with fire-retardant polyethylene core and wood with treatment for fire retardancy), but there were combustible façade like rein paint at which flame propagation didn't occur with heat output of $600 \mathrm{~kW}$. JIS A 1310 with heat output of $900 \mathrm{~kW}$ could make differences more remarkably in terms of flame propagation behaviour and heat flux measured at the specimen's top. In this research, it was clearly found that JIS A 1310 with heat output of $900 \mathrm{~kW}$ could relatively make fire performance clear of various types of combustible exterior façades.

Authors would like to acknowledge specimen suppliers, technicians and students for their contribution to façade fire tests in this paper. Especially, we wish to thank Yutaka Tanaike for great contribution to calculating heat release rate by oxygen consumption method.

\section{References}

[1] H. Yoshioka et al.: "Study of Test Method for Evaluation of Fire Propagation along Façade Wall with Exterior Thermal Insulation," Fire Science and Technology, 30 (2011) No. 1, pp. 27-44.

[2] Hideki Yoshioka et al.: "Façade Tests on Fire Propagation along Combustible Exterior Wall Systems", Fire Science and Technology, 33, No. 1, pp. 1 15, 2014.

[3] JIS A 1310: 2015, Test method for fire propagation over building façades.

[4] ISO 13785-1 \& 2:2002, Reaction-to-fire tests for façades -Part 1: intermediate-scale test and Part 2: Large-scale test. 